\title{
THE SECOND FOREIGN LANGUAGE TEACHING AT THE MILITARY ACADEMY OF LITHUANIA (ON THE BASIS OF AUDIOVISUAL METHOD)
}

\author{
Assoc. Prof. Dr. Jelena Kazimianec, Assoc. Prof. Dr. Dileta Jatautaitė \\ General Jonas Žemaitis Military Academy of Lithuania
}

\begin{abstract}
Nowadays an active search for new methods and techniques of teaching foreign languages is taking place very intensively. That meets the current state of methodological science and the rapid development of the world community as a whole. Intensive technologization and computerization of all spheres of human life, which led to creation of a firm habit of young people to perceive information from the screen, led to the active penetration of audiovisual means of learning in the system of education at schools and universities. Authentic video and various videos created by methodologists specifically for educational purposes are used more and more frequently in the process of foreign language teaching. The use of video clips at the foreign language lessons perfectly suits to the tasks which foreign language teachers face in the context of the development of active multilingualism in the Lithuanian society. The article highlights the use of audiovisual method in teaching the second foreign languages at the Military Academy of Lithuania. The analysis of the advantages and disadvantages of this method is also produced as well as the requirements for authentic audiovisual materials which can be used for educational purposes and the technology of methodological development of authentic video material for its use in foreign language course. The authors emphasize that this method allows economizing learning time and intensifying the educational process.
\end{abstract}

Keywords: audiovisual method, motivation, video clip, authentic audiovisual materials, intertext.

\section{Introduction}

An active search for new methods and techniques of teaching foreign languages is in progress now. It should go together with the current state of methodological science and the rapid development of the world community as a whole. Intensive technologization and computerization of all spheres of human life, which led to creation of a firm habit of young people to perceive information from the screen, led to the active penetration of audiovisual means of learning in the system of education at schools and universities. Authentic video and various videos created by methodologists specifically for educational purposes are used more and 
more frequently in the process of foreign language teaching. Moreover, the real life including all features of natural speech communication comes to the class with the help of video. It should be emphasized that the use of video clips at the foreign language lessons perfectly suits to the tasks which foreign language teachers face in the context of the development of active multilingualism in the Lithuanian society.

The goal of this research is to reveal the most important features of cinema which are relevant for educational purposes; to identify the advantages and disadvantages of audiovisual method as an effective way to intensify the educational process and the specifics of its use in teaching foreign languages; to analyze the process of selection and methodological development of authentic video materials used in foreign language courses; to determine the sequence of work with it in the classroom. The descriptive and analytical methods are applied in his article. The investigation was conducted on the material of teaching the Russian, German and French languages.

The audiovisual method is successfully used at the Military Academy of Lithuania when teaching Russian, French and German as the second foreign language.

\section{The second foreign language teaching at the Military Academy of Lithuania}

Table 1 shows that Russian is the most popular foreign language as $87 \%$ of cadets have preferred it in 2018, whereas only $9 \%$ and $4 \%$ decided to learn German and French, respectively. But we have chosen Russian as an illustrative material for the report because of its popularity among cadets.

Table 1. The choice of the second foreign language in 2018

\begin{tabular}{|c|c|c|}
\hline Russian & German & French \\
\hline $87 \%$ & $9 \%$ & $4 \%$ \\
\hline
\end{tabular}

The Russian language has been taught at the Academy since 2013. Simple statistics show that the popularity of this subject is growing: $25 \%$ of cadets decided to learn Russian in 2013. Every year, the number of learners was increasing as it is shown in the table below, and 87\% of cadets chose Russian in 2018 .

Table 2. The number of cadets who have chosen to study Russian

\begin{tabular}{|l|l|l|l|l|l|}
\hline 2013 & 2014 & 2015 & 2016 & 2017 & 2018 \\
\hline $25 \%$ & $31 \%$ & $42 \%$ & $61 \%$ & $68 \%$ & $87 \%$ \\
\hline
\end{tabular}


The secret of this dynamics is based on a number of factors (objective and subjective) that are not the subject of the analysis. We would like to mention only one of them: "soldier's radio". It means that rumors about Russian classes spread very quickly. Cadets say that "cartoons and movies are shown in the Russian class" and the lessons themselves become interesting, illustrative and they give a good result.

\section{The audiovisual method}

We must admit that methodologists and teachers of foreign languages face at least three key problems that are closely related to each other:

1. Strengthening students' motivation to learn a particular foreign language.

2. The search and development of adequate educational materials which are attractive to the learners and correspond to the recommendations and achievements of modern linguadidactics.

3. Creating a favorable emotional learning atmosphere in a foreign language lesson which contributes to the maximum activity of all students of the group in educational process and provides better and faster learning of material (Прессман, 1965, 9).

It is obvious that the motivation of students is directly related to the educational materials offered to them and to the emotional atmosphere in the classroom. The atmosphere itself is determined by how meaningful, compositionally attractive and masterfully methodically developed the proposed for learning texts, exercises, videos, etc. are.

Naturally, an important role in the learning process is played by the teacher's personality, his/her professionalism, the ability to create an environment in the classroom that is conducive to communication in a foreign language. All this makes us think about what educational materials should be introduced in the classroom and how to present them to students, what methods and techniques to use. It is not a secret that our time is characterized by the computerization of all spheres of human society. So it is necessary to bring the process of teaching a foreign language closer to the way of life familiar to modern young people and at the same time try to preserve the rational grain of the traditional model of learning. On the other hand, there is one more very important task, i.e. to intensify the learning process especially while teaching the second foreign language because of the limited amount of study time. Thus, the teacher has to find special ways to present as much new material as possible per unit of study time.

So, what is the audiovisual method?

The essence of the audiovisual method lies in the fact that the means of visual and audio clarity (visualization) are intensively used in the foreign language teaching. The presented lexical and grammatical material is typical of the conversational style of speech and is most often limited by given audio-video material. As a rule, the 
learning process itself takes less time. Therefore, the use of audiovisual method in a foreign language course seems very promising, taking into account the cognitive and communicative orientation of language teaching in general.

In our opinion, the following three features of film materials are extremely important for the educational process:

1. Visualization. A film is the most accurate copy of reality; it helps to influence a student's personality through image.

2. Dynamism. The mobility of shown frame-pictures and rapid change of speech situations give fertile ground for the development of linguistic cognition and communication skills.

3. Power over time and space. Cinema makes it possible to move us to a country where the language is spoken, to stand "over time" immersing a viewer in a historical excursion: cinema can show what happened in the distant past and what will happen in the future.

However, at least two more very important features of the cinema should be added to the above-mentioned. Firstly, entertaining, exciting (fascination) and attractiveness to a modern young man. Secondly, well-chosen and of a good quality video could emotionally positively inspire a cadet and awake his/her desire to debate (to discuss) and in this way to contribute to the supportive learning climate in the classroom.

On the other hand, the audiovisual method has some shortcomings (disadvantages). The disadvantages of the audiovisual method, in our opinion, are the following:

- the difficulty of developing authentic audiovisual materials for learning purposes;

- a huge amount of time needed to find the right video;

- difficulties of the systematization of grammatical material;

- provocation to some revival in the audience - and because of this the discipline control becomes sometimes a problem.

There is a wide choice of different types of audio-video materials and a great number of student textbooks for learning a foreign language based on these materials. They can be used for the accomplishment of various educational tasks. Videos used as training materials may be:

- basic complex audiovisual courses, where authentic video material is the organizing center of the lessons;

- student textbooks which are developed specifically on the basis of the films made for training purposes;

- video clips are chosen by the teacher's decision from a variety of video and film footages relevant to the study topic (Казимянец, 2011, 13-14);

- artistic interpretation of the lyrics, the works of bards and rockers (Гончар, 2011, 27).

Considering the noted above audiovisual materials used for the Russian 
language teaching as well as for other languages at high school, the preference, from our point of view, should be given to authentic video materials. They have a very special property of cinema, i.e. to be an actual reflection of people's life. Moreover, their usage brings the lesson closer to the usual living conditions of young people, revives the educational process making it entertaining and interesting. For example, authentic video materials, which are the fragments of famous Russian movies and animated films, can be offered as training materials at the Russian lessons.

However, not all authentic video materials are suitable as teaching means at the foreign language lesson. The right choice is a very important task for a foreign language teacher. On the basis of many years' experience, we have developed a number of clear criteria for selecting video material for educational purposes.

1. First of all, it is very important to take into account the relevance of the language study in the context of different cultures. This means that a cognitive base common to a native speaker should be created for communication in a foreign language. That is why we consider the presence of a certain cultural background in the video as a fundamental criterion (Казимянец, 2011, с.194-195).

2. For the implementation of assigned tasks in the selected video, there must be enough lexical, grammatical and phonetic material.

3. If the video material is an animated or feature film or just its part, the film itself should be a kind of intertext, that is, a film should be known to the majority of native speakers. The video should also contain typical conversational situations, expressions, well-known names used by native speakers in their everyday life.

4. The video material selected by a teacher must satisfy the taste and age of students as well as the level of their practical language proficiency (skills).

5. The video material offered for viewing at class should have a structural completeness (a clear composition in which the beginning, the middle and the end can be easily singled out).

6. If the video material is a kind of video clip, its content should be directly related to the main topic of the lesson.

7. The content of the video should encourage trainees to discuss what they have seen and inspire them to look for some additional information on this topic and to share it with the classmates. It would be perfect if the video could motivate them to produce similar dialogues using the learned lexical and grammatical units in game communication situations.

8. The video should have multilayer structure (to contain a variety of linguistic, paralinguistic and cultural material) (Казимянец, 2014, 331-332).

9. The video used as a teaching material must be performed at high cinematic level (the video must be a cinema production of high quality) (Казимянец, 2010, 69).

10. The video material offered for viewing at class should contribute to the creation of a favorable and relaxed atmosphere for communication in a foreign language and cause positive emotions providing the best perception of the educational material. 


\section{The video clip should be politically correct.}

However, no matter how good and interesting the film material chosen by the teacher is, even if it fully satisfies all the requirements mentioned above, the success of the audiovisual method is achieved only through the preliminary methodological development of this material by the teacher. This work requires a lot of time, creative efforts, high professional skills and even imagination.

When preparing for a lesson with a carefully selected audiovisual component, the teacher must first of all determine the range of conversational topics to which the selected video can serve as an illustration. Prior to the viewing, the teacher must determine which grammatical issues can be studied on this material and think over his introductory remarks. Then he/she has to create a phonogram of the text sounding from the screen.

The graphic text of the phonogram is useful for adequate understanding of the most difficult moments of the plot. In addition, it serves as a good material for developing reading skills and is used by students to prepare game tasks concerned producing their own dialogues on the topic of the plot. The teacher also develops a system of various exercises associated with viewing. These exercises can be divided into the following three groups: introductory exercises recommended before video performance; tasks and exercises which accompany each episode and are performed during the video watching and final exercises which are done after video performance. The final exercises are supposed to consolidate the studied material. This makes it possible to develop listening, reading, speaking and writing skills. If it is necessary (if the teacher considers it appropriate), additional texts are offered to cadets for classroom and home reading.

Let us emphasize that the task of additional texts is to expand the thematic and vocabulary range of the lesson, to introduce necessary grammatical structures and to stimulate and provide real language communication at the lesson, while the audio text is used, first of all, as the basis for the formation of listening skills and understanding of the sounding speech as well as to work on the correct pronunciation and intonation. Besides that, the principle of repetition of language material in all types of language activities at a higher level is implemented on the basis of additional texts. These texts, as a rule, contain rich historical and cultural information. This, for example, can be a piece of information about the Russian culture, traditions and customs of the Russian people, as well as proverbs, sayings, idioms, which are the key to the understanding of the Russian national character. Special additional texts are used to develop writing, spelling and grammar skills.

Working with video in the classroom also has some specific features. There are a few main stages. First of all, the teacher should start with an introductory talk, preliminary lexical work and exercises recommended before video performance. After that, trainees view the video for the first time with (or without) teacher's comments. Then, we work with the video material during the second view of each episode separately and perform tasks and exercises after each episode. The last 
stage is the final viewing and work on the final exercises in order to consolidate the studied material. Control task (composition, presentation, test and review) is the compulsory moment for this stage.

Table 3. How to work with video material (stages)

- Introductory talk of the teacher;

- Preliminary lexical work and exercises recommended before video performance;

- Video viewing;

- Work with the video material during the second view of each episode; perform tasks and exercises after each episode;

- Final viewing and working on exercises in order to consolidate the studied material;

- Control task (composition, presentation, test and review) (Казимянец, 2016, 234).

\section{Conclusions}

- In conclusion, it should be noted that the use of audiovisual method in foreign language classes is particularly effective in the absence of a real speech environment, as it allows to present the real communicative process in all variety, including verbal and nonverbal means of communication used by native speakers in various communication situations.

- The use of audiovisual method is a perfect way to economize learning time and intensify the educational process in whole.

- Among many videos used as teaching means, preference should be given to authentic video.

- When selecting authentic video material for teaching purposes, it is strongly recommended to take into account a number of the above-mentioned criteria.

- Moreover, the key to the success of the lesson with a video component is a correct choice of the video material and its qualitative and well-thought-out methodological development by the teacher.

\section{Literature}

1. Гончар И.А. 2011. Звучащий текст как объект методики в аспекте РКИ. Русский язык за рубежом, N 2, с. 25-31.

2. Kazimianec J. 2014. Аутентичные видеотексты на занятиях по иностранному языку. Ugdymo veiksniai mokymo(si) kontekste globalizacijos sąlygomis. Mokslinių straipsnių rinkinys. Vilnius, pp. 325-344.

3. Казимянец Е. 2011. К вопросу об использовании киноматериалов на занятиях по РКИ в рамках диалога культур. Язык $u$ межкультурные 
коммуникации. Материалы III Международной научной конференции МинскВильнюс 17- 20 мая 2011 года. Минск: БГПУ, с. 194-195.

4. Казимянец Е. 2010. Реализация принципа интерактивности в учебной книге по аудиовизуальному курсу русского языка. Žmogus ir žodys. Научные труды.ВПУ. N12(3), Vilnius pp. 67-72.

5. Казимянец Е., Ятаутайте Д. 2016. Технология методической разработки и использования видеоматериала на занятиях по иностранному языку (на примере РКИ). Kalba ir kontekstai. N VII (1), 2 dalis. Vilnius, pp. 226-239.

6. Прессман Л.П. 1965. Использование кино и телевидения для развития речи учащихся. Москва, 160 с. 


\title{
ANTROSIOS UŽSIENIO KALBOS MOKYMAS GENEROLO JONO ŽEMAIČIO LIETUVOS KARO AKADEMIJOJE (audiovizualinio metodo pagrindu)
}

\author{
Doc. dr. Jelena Kazimianec, doc. dr. Dileta Jatautaitė \\ Generolo Jono Žemaičio Lietuvos karo akademija
}

\section{Santrauka}

Naujoje užsienio kalbų mokymo(si) paradigmoje intensyviai vyksta inovatyvių užsienio kalbų mokymo metodų paieška, nes šis poreikis kyla dẻl dabartinio metodologijos mokslo nuolatinio kitimo ir sparčių geopolitinès situacijos pokyčių. Intensyvus technologijų, kompiuterių taikymas įvairiose žmonių gyvenimo srityse privertè mokslininkus ieškoti ir adaptuoti mokymo(si) metodus prie naujo jaunimo ịpročio suvokti ir apdoroti informaciją per vaizdines priemones. Vadinasi, tai paskatino aktyvų audiovizualinių mokymo(si) priemonių plitimą ir jų integravimą ị užsienio kalbų mokymo(si) procesą visose švietimo ịstaigose ir universitetuose. Šiais laikais jau nieko nenustebins vis dažniau naudojami autentiški vaizdo įrašai ir garso vaizdo įrašai, kurie specialiai yra sukurti mokslininkų metodininkų edukaciniais tikslais. Tyrime taikyti aprašomieji ir analizès metodai. Tyrimo metu buvo nustatyta, kad trumpi vaizdo filmukai puikiai tinka visų (rusų, vokiečių ir prancūzų kalbų) užsienio kalbų lygių kūrimo užduotims, kai dėstytojai susiduria su sunkumais, dirbdami daugiakalbystės raidos kontekste. Straipsnyje analizuojamas audiovizualinio metodo taikymas antrosios užsienio kalbos mokymo Generolo Jono Žemaičio Lietuvos karo akademijoje procese. Straipsnyje taip pat yra pateikiamas šio metodo taikymo privalumų ir trūkumų lyginamoji analizè. Šio straipsnio autoriai pateikia dèstytojams rekomendacijas ir reikalavimus dirbant su autentiška vaizdine bei originalia vaizdo medžiaga ir kitomis metodikų kūrimo technologijomis, skirtoms naudoti užsienio kalbų pratybose bei paskaitose dirbant su kariūnais bei KAS klausytojais. Autoriai pabrěžia, kad šis audiovizualinis metodas ženkliai taupo mokymo(si) laiko ir efektyvina švietimo procesą.

Pagrindiniai žodžiai: audiovizualinis metodas, motyvacija, vaizdo įrašas, autentiškos audiovizualinès priemonès, intertekstas. 


\section{AUTORIŲ LYDRAŠTIS}

Autoriaus vardas, pavardė: Jelena Kazimianec

Mokslo laipsnis ir vardas: humanitarinių mokslų daktarè, docentė

Darbo vieta ir pareigos: Generolo Jono Žemaičio Lietuvos karo akademijos Užsienio kalbų katedros docentè

Autoriaus mokslinių interesų sritys: dabartinė rusų kalba, rusų kalbos gramatika, lingvokultūrologija, svetimujų kalbų dėstymo didaktika, sociolingvistika, komparatyvistinè lingvistika.

Telefonas ir el. pašto adresas: +370 687 59272, jelena.kazimianec@lka.lt

Autoriaus vardas, pavardė: Dileta Jatautaitè

Mokslo laipsnis ir vardas: socialinių mokslų daktarè, docentė

Darbo vieta ir pareigos: Generolo Jono Žemaičio Lietuvos karo akademijos Užsienio kalbų katedros vedèja docentė

Autoriaus mokslinių interesų sritys: psicholingvistika, glotoedukologija, edukologija, tradiciniai ir netradiciniai kalbų mokymo metodai bei metodologija, psicho-edukologinai kalbų mokymo ir išmokimo pagrindai

Telefonas ir el. pašto adresas: 85 2103560; dileta.jatautaite@mil.lt

\section{AUTHORS' COVER LETTERS}

Author's name, surname: Jelena Kazimianec

Academic degree and name: Associate Professor, Doctor

Workplace and position: General Jonas Žemaitis Military Academy of Lithuania, Department of Foreign Languages, Associate Professor

Author's research interests: modern Russian, Russian grammar, comparative linguistics, foreign language teaching methods, social linguistics, lingua-culturology

Telephone and e-mail address: +370 68759 272, jelena.kazimianec@1ka.lt

Author's name, surname: Dileta Jatautaitè

Academic degree and name: Associate Professor, Doctor

Workplace and position: General Jonas Žemaitis Military Academy of Lithuania, Department of Foreign Languages, Head

Author's research interests: psycholinguistics, glotoeducology, traditional and non-traditional language teaching methods and methodology, psychoeducational basis in language learning and acquisition

Telephone and e-mail address: +370 5210 3560; dileta.jatautaite@mil.lt 